\title{
Selection of Renewable Energy in Rural Area Via Life Cycle Assessment-Analytical Hierarchy Process (LCA-AHP): A Case Study of Tatau, Sarawak
}

\author{
Cyril Anak John ${ }^{1}$, Lian See Tan ${ }^{1, * \mathbb{D}}$, Jully Tan ${ }^{2}$, Peck Loo Kiew ${ }^{1} \mathbb{D}$, Azmi Mohd Shariff ${ }^{3} \mathbb{D}$ \\ and Hairul Nazirah Abdul Halim 4 (D)
}

Citation: John, C.A.; Tan, L.S.; Tan, J.; Kiew, P.L.; Shariff, A.M.; Abdul Halim, H.N. Selection of Renewable Energy in Rural Area Via Life Cycle Assessment-Analytical Hierarchy Process (LCA-AHP): A Case Study of Tatau, Sarawak. Sustainability 2021, 13, 11880. https://doi.org/10.3390/ su132111880

Academic Editors: Georgios Tsantopoulos and Evangelia Karasmanaki

Received: 28 September 2021 Accepted: 25 October 2021 Published: 27 October 2021

Publisher's Note: MDPI stays neutral with regard to jurisdictional claims in published maps and institutional affiliations.

Copyright: (c) 2021 by the authors. Licensee MDPI, Basel, Switzerland. This article is an open access article distributed under the terms and conditions of the Creative Commons Attribution (CC BY) license (https:/ / creativecommons.org/licenses/by/ $4.0 /)$.
1 Malaysia-Japan International Institute of Technology, Universiti Teknologi Malaysia, Jalan Sultan Yahya Petra, Kuala Lumpur 54100, Malaysia; cyriljohn19@gmail.com (C.A.J.); plkiew@utm.my (P.L.K.)

2 School of Engineering, Monash University Malaysia, Jalan Lagoon Selatan, Bandar Sunwa 47500, Malaysia; tan.jully@monash.edu

3 Chemical Engineering Department, Universiti Teknologi PETRONAS, Seri Iskandar 32610, Malaysia; azmish@utp.edu.my

4 Faculty of Chemical Engineering Technology, Universiti Malaysia Perlis, Kompleks Pusat Pengajian Jejawi 3, Arau 02600, Malaysia; hairulnazirah@unimap.edu.my

* Correspondence: tan.liansee@utm.my; Tel.: +603-22031311

\begin{abstract}
With a growing global population and energy demand, there is increasing concern about the world's reliance on fossil fuels, which have a negative impact on the climate, necessitating the immediate transition to a cleaner energy resource. This effort can be initiated in the rural areas of developing countries for a sustainable, efficient and affordable energy source. This study evaluated four types of renewable energy (solar, wind, biomass, and mini-hydro energy) using the integrated Life Cycle Assessment (LCA) and Analytical Hierarchy Process (AHP) approaches to select the best renewable energy source in Tatau, Sarawak. The criteria under consideration in this study included the environment, engineering and economics. The LCA was used to assess the environmental impact of renewable energies from gate-to-grave boundaries based on $50 \mathrm{MJ} /$ day of electricity generation. The AHP results showed that solar energy received the highest score of 0.299 in terms of the evaluated criteria, followed by mini-hydro, biomass and wind energy, which received scores of $0.271,0.230$ and 0.200 , respectively. These findings can be used to develop a systematic procedure for determining the best form of renewable energy for rural areas. This approach could be vital for the authorities that are responsible for breaking down multi-perspective criteria for future decision making in the transition into renewable energy.
\end{abstract}

Keywords: renewable energy; life cycle assessment; analytical hierarchy process; multi-perspective criteria

\section{Introduction}

Petroleum crude oil and natural gas are the main energy sources in Malaysia [1]. The overall conventional fuel business, on the other hand, has deteriorated due to price instability, supply insufficiency, and the environmental damage it causes, thereby ushering us into the inevitable era of renewable energy [2]. In 2017, renewable energy only accounted for approximately $5.8 \%$ of Malaysia's total energy consumption [1]. The Malaysian government has set a target of $20 \%$ renewable energy, in terms of total electricity generation, by 2025 [3]. According to Abdullah et al. [4], Malaysia has a wide range of opportunities and potential for focusing on renewable energy, particularly solar, wind, hydro, biogas and biomass. However, realizing this potential would necessitate an immense effort from the government in terms of providing incentives as well as developing and implementing systemically effective policies. 
It was estimated that $4 \%$ of the region in Sabah and $15 \%$ of that in Sarawak still have no access to electricity. In response to this, the Malaysian government has set a goal of providing modern energy facilities to as many people as possible, particularly in the remote parts of Sarawak and Sabah [5]. Due to the geographic profile of such places, increasing the grid's electricity supply is a challenge. Power distribution is uneconomic due to uneven terrain and dense forest. High transmission loss is also an issue, implying that a grid power supply in remote areas is not possible [6]. On the contrary, off-grid electricity, which can be generated using renewable energy sources such as solar, wind, or hydro technologies, can be used to power remote areas. The available resources can boost rural electrification capacity and benefit the villagers as an economic strategy and a sustainable source of energy.

In rural areas, the local electrical authorities commonly opted for diesel-powered generators or, most recently, the hybrid-solar system as a quick and short-term fix to supply electricity to essential facilities such as remote schools, clinics, administrative offices, and small villages for a limited period of time per day [7]. Nonetheless, the Sarawak state government deserves credit for increasing the state-level electricity coverage from $79.2 \%$ to $90 \%$ between 2009 and 2015 [8]. To avoid this rural electrification initiative failing on a long-term basis, extensive planning in terms of implementation, technical and social difficulties must be done [9]. Therefore, energy planning analysis should be done in a more holistic manner, such as integrating the methods of the Life Cycle Analysis (LCA) and Multi-Criteria Decision Making (MCDM) [10]. This would allow for a more comprehensive analysis, as well as the development of a new analytical tool to replace the conventional cost-benefit or techno-economic analysis.

The practical application of the LCA to product or process design and development in order to reduce aggregate environmental impacts is gaining traction, either through the modification of some input variables or a scenario analysis. Based on the LCA analysis of supercritical carbon dioxide extraction of caffeine from coffee beans, De Marco et al. [11] claimed that when a portion of the electricity at the grid was replaced with electricity produced by photovoltaic (PV) panels, the environmental impact could be reduced by $176 \%$ in terms of human health, $10.3 \%$ in terms of ecosystem diversity, and $16.1 \%$ in terms of resource availability. On the other hand, based on the LCA analysis conducted by Gallucci et al. [12], the authors reported that using PV energy as a renewable energy source in the production of hollow glass containers for food packaging was able to significantly reduce the global warming potential.

Likewise, MCDM has been implemented in recent years to evaluate many solutions to real-world problems relating to policy and strategy [13]. Hassan et al. [14] used a multicriteria decision-making tool in the form of the Analytical Hierarchy Process (AHP) in order to analyze renewable generation sources in Saudi Arabia. A similar approach was also taken by Algarín et al. [15] in evaluating the renewable energy sources of rural areas in the Caribbean region of Colombia. A study was done by Das [16] that integrated the AHP and Quality Function Deployment (QFD) methods in order to determine the most viable renewable energy source for the state of Maharashtra. Hilorme et al. [17] developed a decision-making model for introducing energy-saving technologies based on the AHP. Zhang et al. [18] studied the economic development of the biomass energy industry in the Heilongjiang province based on the AHP. Nevertheless, the application of the combined LCA-MDCM methodologies for the analysis of renewable energy in an Asian context is limited, with Ren et al. [19] evaluating the sustainability of renewable fuel production, i.e., bioethanol. Hence, in this study, a robust systematic evaluation of renewable energy systems, using the integrated LCA-AHP methodologies, was expanded for the analysis of the Asian regions, particularly Malaysia, in order to promote the sustainable development of zero-carbon technology.

In recent years, several studies have been conducted to assess the current state of renewable energy in Malaysia. According to Hannan et al. [5], the rural electrification effort in Malaysia requires more attention in order to contribute to the country's future energy 
security and sustainability. Based on a study by Basri et al. [20], the abundance of renewable energy resources in Malaysia could potentially produce a stable supply of renewable energy. Despite this, there is no clear approach for choosing the most suitable type of renewable energy to meet the complicated economic, social, and environmental requirements.

Unsystematic decision making in the determination of the best renewable energy that can satisfy the needs of each individual rural location could hamper the successful implementation of the rural electrification initiative. Various elements, including environmental, engineering and economic factors, must be considered in order to overcome this. The application of the Life Cycle Assessment-Analytical Hierarchy Process (LCA-AHP) as a decision-making tool would allow for a comprehensive evaluation that could take such considerations into account. Tatau in Bintulu, Sarawak, was chosen as the case study for this study.

This research aims to characterize pollutant emissions and to determine the cost of generating electricity using different renewable energy systems. The environmental impact of different renewable energy systems was determined using the LCA method while the best renewable energy for Tatau, Bintulu from a combined engineering, environmental and economic perspective was evaluated using the AHP method. The findings of this study would provide a systematic process for determining the most appropriate renewable energy system for the rural area of Tatau, Sarawak. This approach will be critical for the authorities that are responsible for breaking down the multi-perspective criteria that may be used in the future system design.

\section{Materials and Methods}

\subsection{Life Cycle Assessment ( $L C A$ )}

The LCA was used to determine the environmental impact of the renewable energy sources. In this study, the LCA data for each renewable energy system was extracted from sources in the literature in order to reflect the global warming potential (GWP) and acidification potential (AP) as their respective environmental factor score. GWP is correlated to greenhouse gas emissions, and it is an indication of the system's potential contribution to climate change. Meanwhile, the AP could indicate the environmental impact of the system as it relates to the acidification of water bodies and soil [21]. This LCA approach, which was based on ISO 14040 and ISO 14044 [22], was comprised of four steps, as shown in Figure 1. The first step was to define the goal and scope of the project. This measure determined the objective, system boundaries, functional unit and assumptions. Then there was the life cycle inventory (LCI), which involved data collection from all stages within the life cycle boundary, including the input, intermediate processes, and output. The third step was the life cycle impact assessment (LCIA), whereby the potential impact on the environment by the system was evaluated. Lastly, the data was interpreted based on the goal and scope definitions, as well as the LCI and LCIA data. The vital points were assessed and suggestions for future improvements were made.

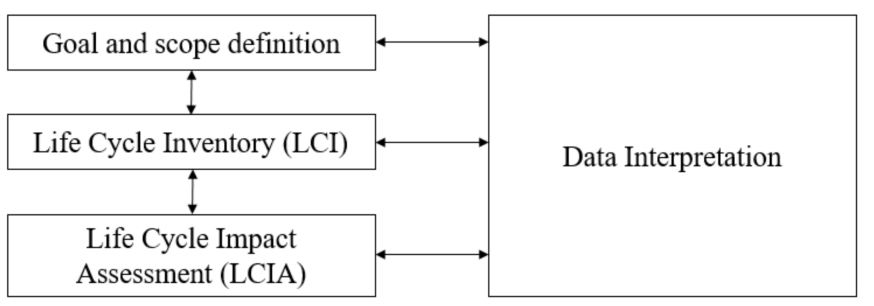

Figure 1. Framework of the life cycle assessment (LCA).

\subsubsection{Goal and Scope Definition}

This study focuses on the potential electrification of the rural area of Tatau, Bintulu using renewable energy. The goal of this assessment was to determine the overall impact of selecting the different renewable energy systems that were evaluated in this study, which 
included solar, wind, biomass and mini-hydro energy, for every $50 \mathrm{MJ} /$ day of energy output. This is equivalent to a total of $13.89 \mathrm{kWh} /$ day of electricity, which was sufficient to power an estimated 25 houses in Tatau, Sarawak, with an average of $2 \mathrm{MJ} /$ day per household of the rural community [23]. Tatau is a district in Bintulu, Sarawak, with a total land size of $4945.80 \mathrm{~km}^{2}$ and a population of approximately 25,000 people. The economic background of Tatau mostly involves the timber and agricultural industries. The rural areas of Tatau are only travelable via timber routes and palm estate paths, one of them being Kakus road [24].

Jong et al. [25] found that Tatau has an abundance of potential for renewable energy due to its strategic location relative to the renewable resources, reasonable distance to road access, considerable population and mild land slope. However, they only focused on evaluating the potential of renewable energy for Tatau, and several other locations in Sarawak, based on geographical data. Therefore, the evaluation that was done in this study aimed to further evaluate the potential renewable energy sources that could be sustainable for rural areas in terms of engineering feasibility, environmental impact, and economic feasibility.

For the four renewable energy systems under evaluation, the environmental impact was assessed from the point of manufacture (gate) to the point of end-of-life (grave). This included the stages of component manufacturing, construction, operation, maintenance, and finally, disposal. Figure 2 illustrates the system boundaries for the renewable energy systems.

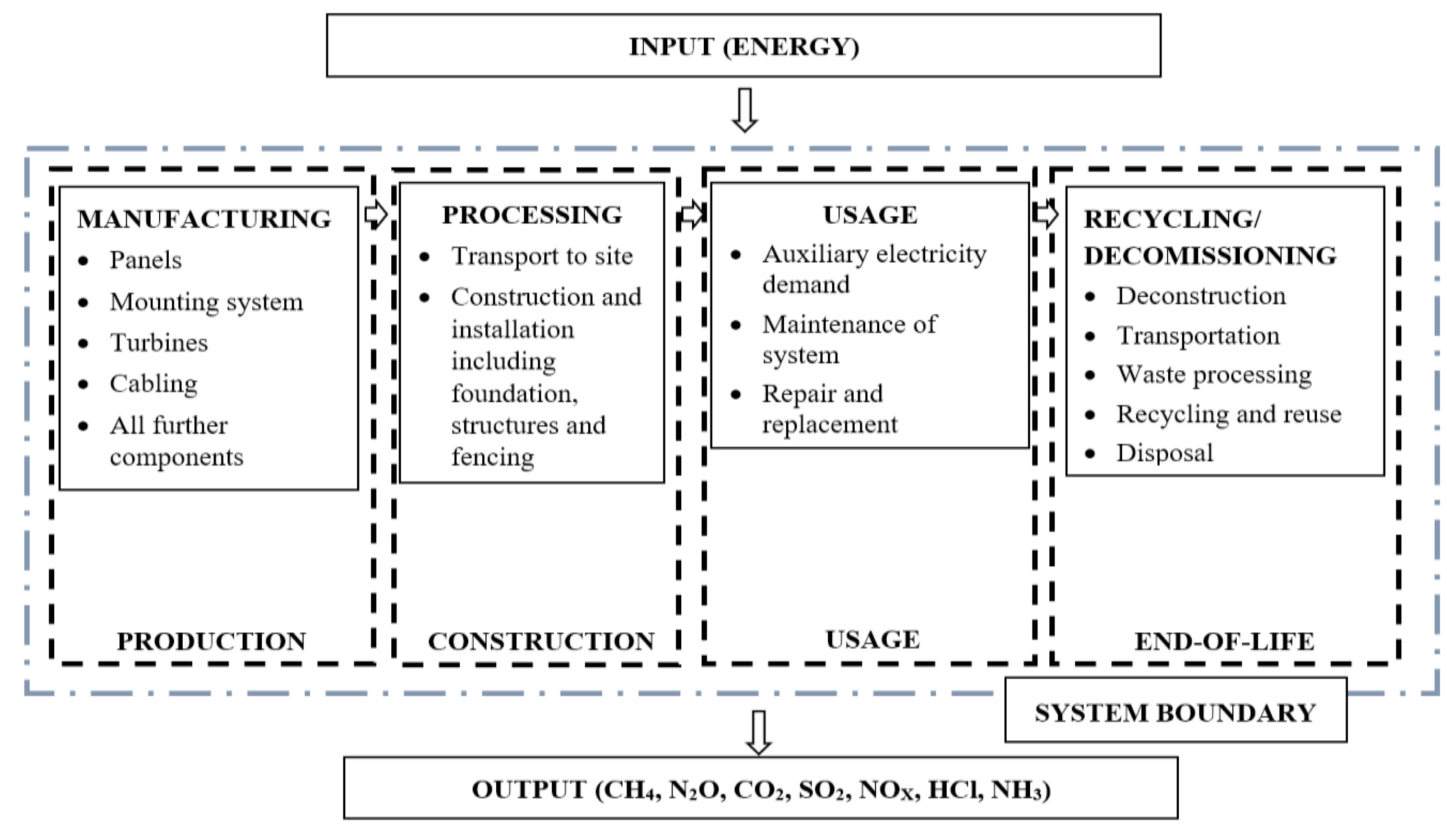

Figure 2. System boundaries for all alternatives in this study.

The energy consumptions and the materials consumed throughout the system boundaries for each renewable energy system were used as inputs in this study. As shown in Figure 2, the system boundary is made up of four stages of processes: production, construction, usage and end-of-life. The production stage of renewable energy started with the extraction of raw materials for the manufacturing of components and their assembly. This includes the assembly of panels, mounting systems, cables, and other components that are required to generate sufficient amounts of electricity. At this stage, only the main materials and quantities required for the production were defined.

Meanwhile, in the construction stage, local land routes and maritime deliveries were considered as the means of system transportations to the site. This study did not take into account transportation from outside of the country, as the energy system could be 
procured from any country, but the entry route to Tatau is consistent, which is through its port. According to Google Maps, the distance for local land transportation from Bintulu's nearest port to the rural area of Tatau was $63 \mathrm{~km}$. The energy consumption during the construction and installation of the foundation, structures and fencing were also included in this stage.

The usage stage of the system involved the demand for auxiliary electricity when necessary. Scheduled maintenance of the system was included as it was vital to inspect its performance and maintain the system's efficiency. This stage also took into consideration any necessary repairs or replacements during the course of its use.

The final phase of the system was the end-of-life stage, which included deconstruction, transportation, recycling and reuse where applicable, and waste processing. The aim was to evaluate the impact of waste recycling and disposal on the environment. It was estimated that the system has a lifespan of 25 years.

- The data for this LCA analysis were extracted from reviews in the literature and publicly available databases. The data were scaled to $1 \mathrm{kWh}$ of electricity produced for all stages before being normalized to $13.89 \mathrm{kWh}$, which is the functional unit of this study. The following assumptions were made for the inventory data collection: Only electricity was included as the input for this study. Other materials were not considered as alternatives would have required the use of exclusive materials for the manufacturing of components [26].

- Electricity used during the production stage was assumed to be generated using natural gas, which had the specific natural energy of $53.6 \mathrm{MJ} / \mathrm{kg}$ [27] and an efficiency of $55.13 \%$ [28]. During the usage stage, self-generated electricity was used for auxiliary electricity demand.

- The transportation stage only included land transportation and did not include sea or air transportation.

- Only output and pollutants, i.e., methane $\left(\mathrm{CH}_{4}\right)$, nitrous oxide $\left(\mathrm{N}_{2} \mathrm{O}\right)$, carbon dioxide $\left(\mathrm{CO}_{2}\right)$, sulfur dioxide $\left(\mathrm{SO}_{2}\right)$, nitric oxide $\left(\mathrm{NO}_{\mathrm{x}}\right)$, hydrogen chloride $(\mathrm{HCl})$ and ammonia $\left(\mathrm{NH}_{3}\right)$, which were related to GWP and AP, were taken into consideration in the LCI.

\subsubsection{Life Cycle Impact Assessment (LCIA) Scope Definition}

The aim of this step was to extract the relevant environmental indicator from the results of the inventory analysis. The impact classification included global warming potential (GWP) and acidification potential (AP). The characterization factors were taken from the literature [26,29-31].

\subsection{Simulation of HOMER Pro}

This study used HOMER Pro version 3.11.2 simulation software to design an optimize a renewable-energy-electrification system for the case study area, i.e., Tatau, Sarawak. The information and details of the actual location served as the input data for the simulation. The details included the renewable resources of the alternatives evaluated, which were solar irradiation, wind speed, biomass resource, and stream flow with regards to the load profile of the case study area. The information was obtained from the coordinates of Tatau, Sarawak. Next, the system was designed based on the specifications and costs of the components that were obtained from sources in the literature and previous project data. The results from the HOMER Pro simulation provided the relevant costs required, which included the capital cost as well as the operation and management costs [32]. The flow chart of the use of HOMER for the optimization process of the proposed renewable energy system is shown in Figure 3.

In terms of load profiles, the average electric consumption for the case study area of Tatau, Sarawak was assumed to be $50 \mathrm{MJ} /$ day or $13.89 \mathrm{kWh} /$ day, based on the average household energy consumption. It is also worth noting that the assumed load profile was based on a working day during the dry season of the year. The energy consumption profile may differ from the input load profile during other seasons. 


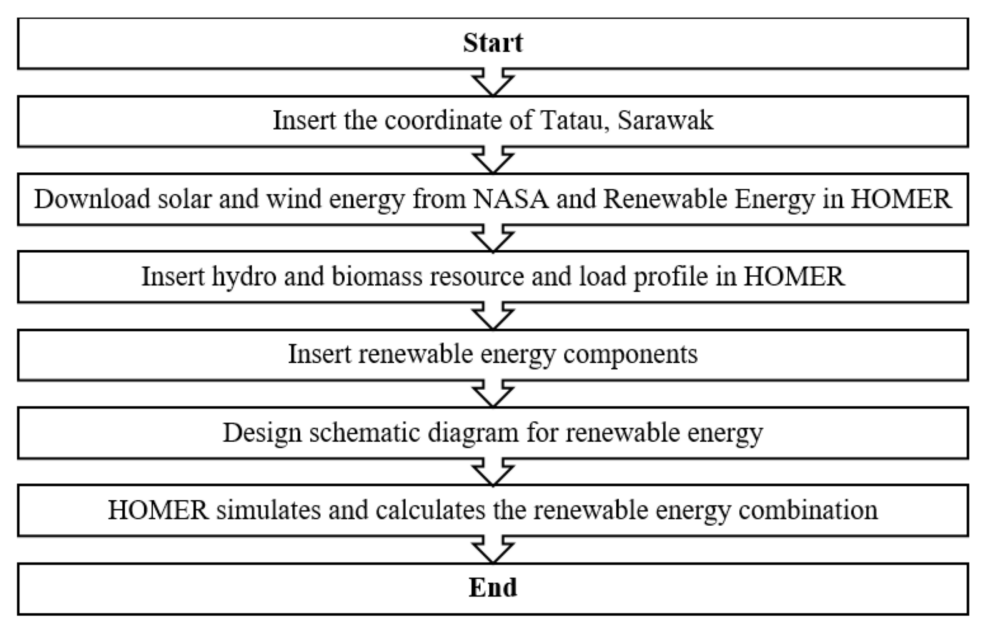

Figure 3. Flowchart of HOMER Pro simulation method.

\subsection{Analytical Hierarchy Process (AHP)}

The initial phase of the AHP involved the division of the multiplex problem into several levels of a hierarchy [33]. The topmost level of this hierarchy represented the main goal of a decision maker. The second level represented the evaluated criteria, and the bottom level corresponded to the alternatives that were under consideration. In some cases, sub-criteria can be considered under the main decision criteria in order to incorporate additional problem-specific decision levels. Following that, pairwise comparison was performed by weighing and ranking the priorities and alternatives. Saaty [34] advocated for the use of measurements on a scale of 1 to 9 and the eigenvector approach for this comparison. This pairwise comparison could be executed on both the quantitative and qualitative characteristics of the alternative energy sources.

The outcome of these steps helped to forecast the impact of each alternative on the overall goal of the hierarchy decision. It also helped to distinguish competing criteria and eventually rank them according to their priorities. Following that, the data were examined in order to identify inconsistencies in the judgements made. As the result obtained may have been subjective, this consistency check was an important step in the AHP method [14]. The final stage of this approach was to evaluate the scores of each criterion, sub-criterion, and lastly, alternative.

\section{AHP Model}

A hierarchical structure was developed in this study which incorporated four levels: goal, main criteria, sub-criteria and alternatives.

(a) Level 0: Goal To determine the best renewable energy system for Tatau, Sarawak.

(b) Level 1: Main Criteria Main criteria in this study were the environment, engineering and economy.

(c) Level 2: Sub-criteria The sub-criteria in this study were the land requirements, environmental impact (global warming potential (GWP) and acidification potential (AP)), resource availability, efficiency of the system, technology maturity, capital cost and operating and management costs.

(d) Level 3: Alternatives The alternatives being assessed in this study were solar, wind, biomass and mini-hydro energy system. The layout of this hierarchy is represented in Figure 4. 


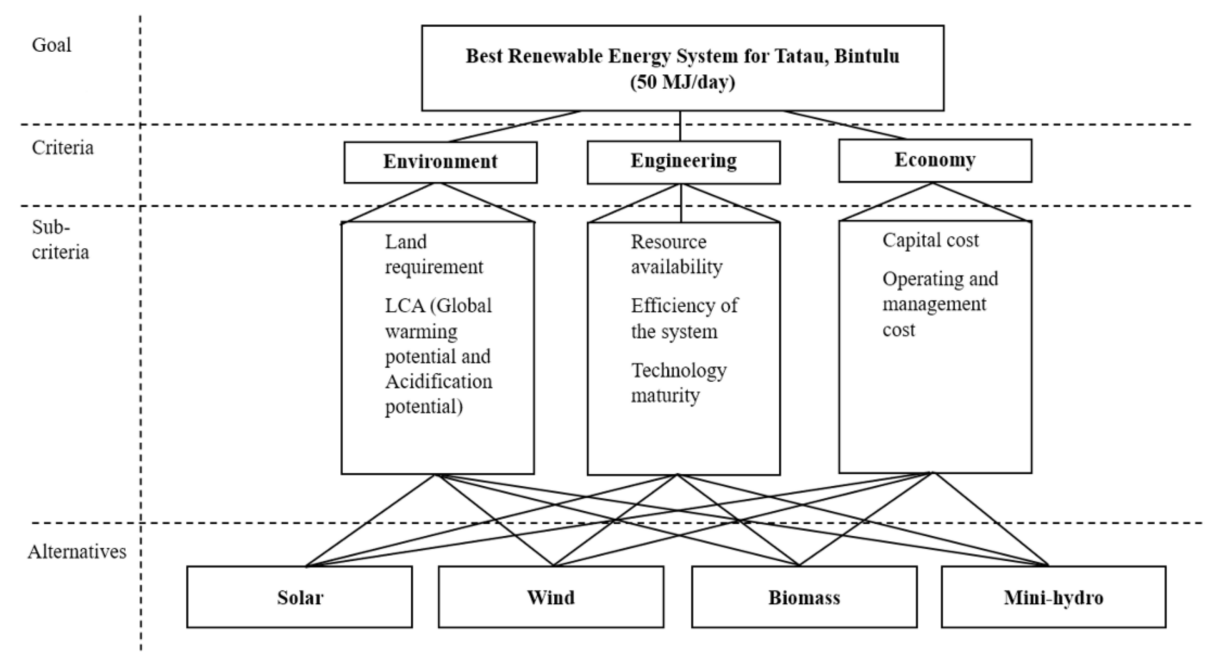

Figure 4. AHP model for this study.

\section{Results}

\subsection{Environmental Impacts of Renewable Energy Alternatives}

Table 1 shows the pollutants emitted by the renewable energy sources that were evaluated in this study, namely solar, wind, biomass, and mini-hydro energy. The pollutants that contributed to the impact assessed in the LCA boundary of this study, which were GWP and AP, were included in the results. The pollutant emissions were classified into four stages within the gate-to-grave boundary of manufacturing, construction, usage and end-of-life.

Table 1. Pollutant emissions of solar energy system [35,36]; wind energy system [35,37,38]; biomass energy system [39,40]; and mini-hydro energy system [41,42].

\begin{tabular}{|c|c|c|c|c|c|}
\hline $\begin{array}{l}\text { Energy } \\
\text { System }\end{array}$ & $\begin{array}{c}\text { Type of Pollutants } \\
(\mathrm{kg} / \mathrm{kWh})\end{array}$ & $\begin{array}{l}\text { Manufacturing } \\
\left(\times 10^{-2}\right)\end{array}$ & $\begin{array}{l}\text { Construction } \\
\left(\times 10^{-2}\right)\end{array}$ & $\begin{array}{l}\text { Usage } \\
\left(\times 10^{-2}\right)\end{array}$ & $\begin{array}{l}\text { End-of-Life } \\
\quad\left(\times 10^{-2}\right)\end{array}$ \\
\hline \multirow{7}{*}{ Solar } & $\mathrm{CO}_{2}$ & 156.14 & 26.80798 & 0.00 & 11.03 \\
\hline & $\mathrm{CH}_{4}$ & 346.98 & 59.55 & 0.00 & 24.52 \\
\hline & $\mathrm{N}_{2} \mathrm{O}$ & 80.50 & 13.82 & 0.00 & 5.69 \\
\hline & $\mathrm{SO}_{2}$ & 80.50 & 13.82 & 0.00 & 5.69 \\
\hline & $\mathrm{NOx}$ & $27,271.27$ & 4680.52 & 0.00 & 1927.15 \\
\hline & $\mathrm{HCl}$ & 232.61 & 39.92 & 0.00 & 16.44 \\
\hline & $\mathrm{NH}_{3}$ & 56.95 & 9.77 & 0.00 & 4.02 \\
\hline \multirow{7}{*}{ Wind } & $\mathrm{CO}_{2}$ & 18.82 & 0.24 & 0.17 & 0.18 \\
\hline & $\mathrm{CH}_{4}$ & 44.46 & 0.56 & 0.39 & 0.43 \\
\hline & $\mathrm{N}_{2} \mathrm{O}$ & 0.37 & 0.01 & 0.00 & 0.00 \\
\hline & $\mathrm{SO}_{2}$ & 3799.77 & 48.20 & 33.23 & 36.54 \\
\hline & NOx & 2991.72 & 37.95 & 26.16 & 28.77 \\
\hline & $\mathrm{HCl}$ & 19.24 & 0.24 & 0.17 & 0.19 \\
\hline & $\mathrm{NH}_{3}$ & 2.89 & 0.04 & 0.03 & 0.03 \\
\hline \multirow{7}{*}{ Biomass } & $\mathrm{CO}_{2}$ & 1.21 & 0.03 & 1.64 & 0.03 \\
\hline & $\mathrm{CH}_{4}$ & 1.81 & 0.04 & 2.46 & 0.04 \\
\hline & $\mathrm{N}_{2} \mathrm{O}$ & 3.54 & 0.08 & 4.79 & 0.08 \\
\hline & $\mathrm{SO}_{2}$ & 1091.65 & 25.04 & 1479.81 & 25.04 \\
\hline & $\mathrm{NOx}$ & $10,832.53$ & 248.46 & $14,684.22$ & 248.464 \\
\hline & $\mathrm{HCl}$ & 209.93 & 4.82 & 284.58 & 4.82 \\
\hline & $\mathrm{NH}_{3}$ & 587.81 & 13.48 & 796.82 & 13.48 \\
\hline \multirow{7}{*}{ Mini-hydro } & $\mathrm{CO}_{2}$ & 10.42 & 5.56 & 1.39 & 0.02 \\
\hline & $\mathrm{CH}_{4}$ & 21.89 & 11.68 & 2.92 & 0.04 \\
\hline & $\mathrm{N}_{2} \mathrm{O}$ & 0.42 & 0.22 & 0.06 & 0.00 \\
\hline & $\mathrm{SO}_{2}$ & 1010.25 & 538.80 & 134.70 & 1.68 \\
\hline & $\mathrm{NOx}$ & 2139.34 & 1140.98 & 285.25 & 3.57 \\
\hline & $\mathrm{HCl}$ & 5.94 & 3.17 & 0.79 & 0.01 \\
\hline & $\mathrm{NH}_{3}$ & 2.38 & 1.27 & 0.32 & 0.00 \\
\hline
\end{tabular}


Based on the aggregated pollutants, the GWP and AP of the renewable energy alternatives are shown in Figure 5. The results showed that solar energy had the greatest impact in terms of GWP and AP, followed by biomass energy and wind energy. Mini-hydro energy exhibited the lowest environmental impact of the four renewable energy sources that were evaluated. Figure 6 shows the percentage of environmental impact contribution in order to further analyze which stage within the gate-to-grave scope was responsible for the GWP and AP emission levels. A significant portion of the aggregated pollutants from solar and wind energy came from the manufacturing stage of the system. According to Mulvaney [43], this was due to the high energy consumption of the solar panel manufacturing process in particular. The processing of raw silicon requires a huge amount of energy as the process involves high temperatures that contribute significantly to carbon emissions. Similarly, the manufacturing phase of the wind energy system requires heating and cooling processes for the fabrication of turbines [44,45]. While the manufacturing stage contributed less to the environmental impact of mini-hydro energy, the construction stage accounted for a significant portion of the pollutants in this system. Concrete production and the transportation of rocks for the construction of dams and tunnels were among the major contributors to the pollutant emissions of a mini-hydro energy system [46]. Biomass energy, on the other hand, was found to emit a higher percentage of pollutants during the usage stage when compared to the other evaluated stages in the system boundary. This could be due to the release of pollutants during the operation of the system as a result of biomass combustion [40].

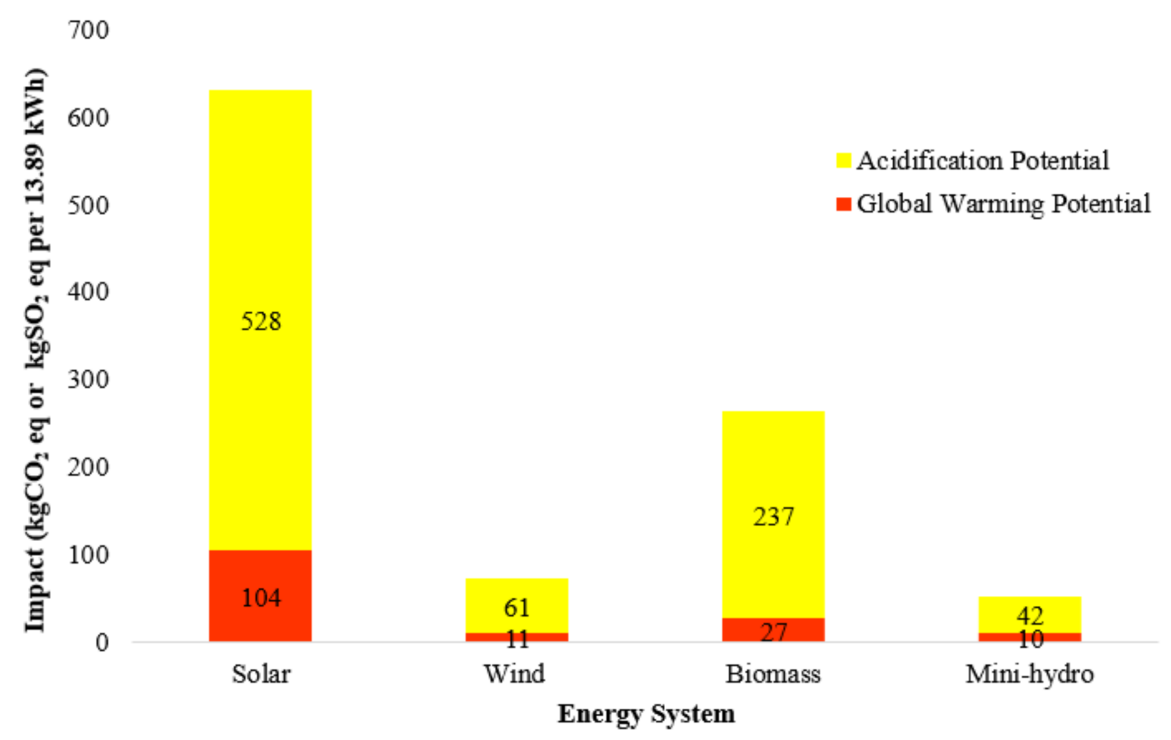

Figure 5. Impact assessment results of the renewable energy alternatives.

\subsection{Cost for Electricity Generation}

Based on the HOMER Pro Simulation, it was found that solar and wind energy demanded the highest costs in terms of building and operating the energy system, with an estimated total of US $\$ 14,821.01$ and US $\$ 14,626.00$, respectively. The capital costs for both energy systems were significantly higher due to the expensive materials needed to manufacture the energy systems $[47,48]$. It was also noted that, according to the simulation, the operational and maintenance costs of a biomass energy system was the highest, at approximately US $\$ 5,447.09$. This was due to the cost of replacing the electrical generator over the course of a year. The replacement was necessary to maintain the efficiency of the system in meeting the electrical load demand [49]. Table 2 shows the summary of the costs needed for renewable energy alternatives in this study, which were simulated using the HOMER Pro simulation software version 3.11.2. 


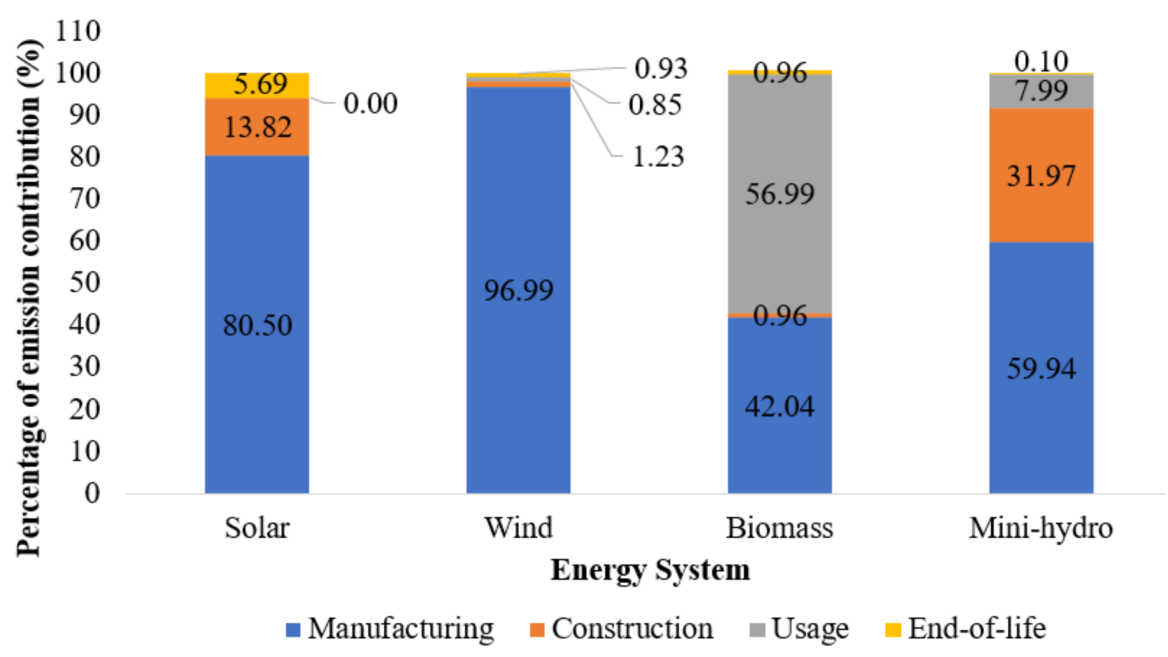

Figure 6. Percentage of emission contribution.

Table 2. Summary of cost * needed for renewable energy alternatives.

\begin{tabular}{ccccc}
\hline Expenditure & $\begin{array}{c}\text { Solar } \\
\text { Energy }\end{array}$ & $\begin{array}{c}\text { Wind } \\
\text { Energy }\end{array}$ & $\begin{array}{c}\text { Biomass } \\
\text { Energy }\end{array}$ & $\begin{array}{c}\text { Mini-Hydro } \\
\text { Energy }\end{array}$ \\
\hline Capital cost (US\$) & $11,618.67$ & $12,337.18$ & 841.75 & $5,782.83$ \\
Operational and maintenance cost (US\$) & $3,202.34$ & $2,288.82$ & $5,447.09$ & 773.38 \\
\hline Total (US\$) & $14,821.01$ & $14,626.00$ & 6288.84 & 6556.21 \\
\hline
\end{tabular}

* The currency exchange rate used was US\$1 = RM4.16.

\subsection{Analytical Hierarchy Process (AHP)}

The results of the environmental impact study and the costs from LCA and HOMER Pro simulation from the previous section yielded the score for the GWP, AP, capital cost, and operational and maintenance cost sub-criteria of the AHP model in Figure 4. In this section, the remaining sub-criteria data were analyzed based on sources in the literature from various studies. The results of various studies were compared to determine the data deviation and average value. Figure 7 shows a summary of the land requirements for each renewable energy alternative that was investigated in this study.

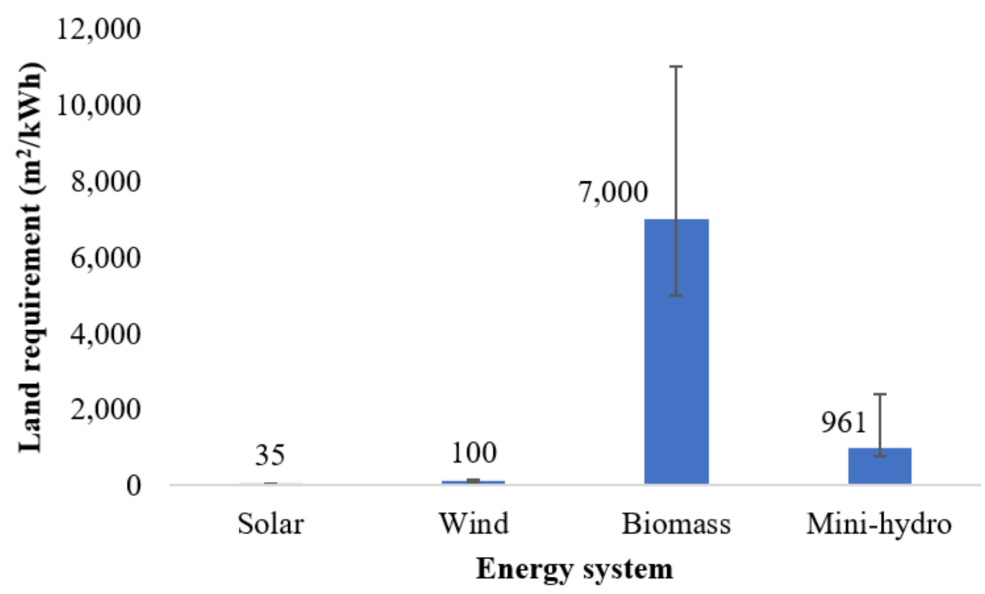

Figure 7. Land requirement of the renewable energy alternatives [50-57].

Biomass energy required the most land in terms of site area, with an average of $7000 \mathrm{~m}^{2} / \mathrm{kWh}$. This was because the biomass resource required a large receiving and processing area [58]. Other studies revealed highly variable land sizes due to the use of different technologies with varying equipment sizes to process the biomass resource. 
As a result of this finding, it was observed that solar energy was the most sustainable renewable energy in terms of land requirement, as it required the least amount of land to build the energy system. This was largely due to the fact that the components of the energy system were small and did not take up much space [59]. Figure 8 shows the availability of resources for all renewable energy alternatives. The results showed that solar energy was leading in terms of its resource availability in Malaysia, with a generation potential as high as $6500 \mathrm{MW}$ due to the high annual solar irradiance of the country [60]. This was followed by mini-hydro energy, with the capacity of $28.9 \mathrm{MW}$. The high annual rainfall and river flow in the proximity of the case study area were deemed as advantageous for the mini-hydro energy system [61].

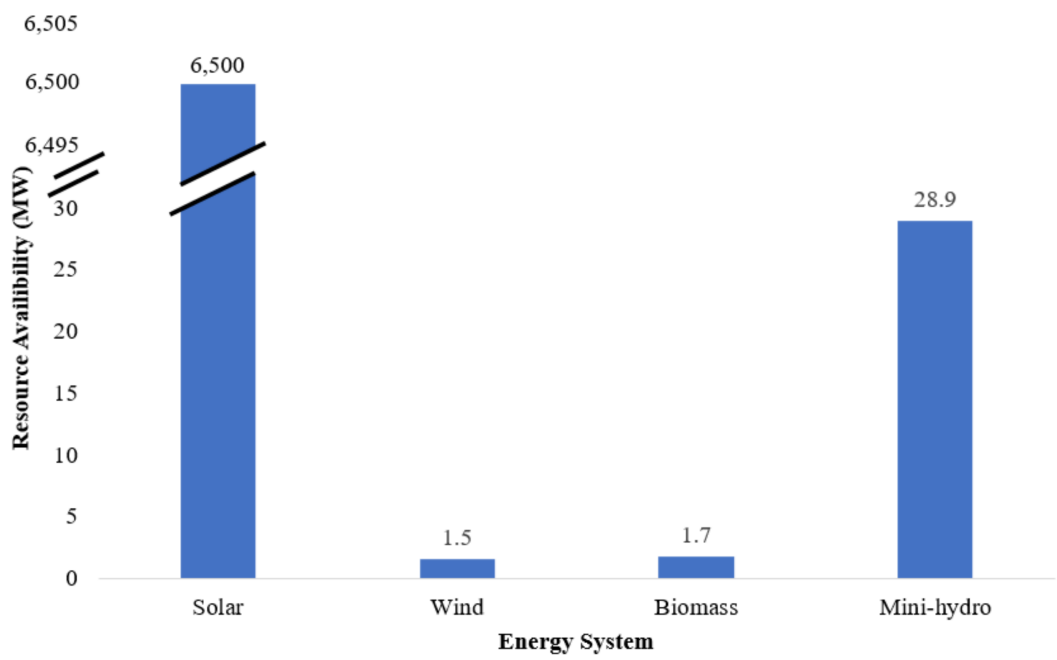

Figure 8. Resource availability of the renewable energy alternatives [32,58,62,63].

In terms of resource availability, solar energy was the most suitable type of renewable energy with the highest generation potential. Wind energy, on the other hand, was the least suitable as the wind speed in the case study area was not sufficient to meet the electrical load demand. This was compounded by the high variability of wind speeds throughout the year in Malaysia, which was not ideal for the output efficiency [48].

Technological maturity was the next sub-criterion under the engineering perspective. Figure 9 shows the maturity of renewable energy alternatives in Malaysia based on the total number of projects completed in the past $[59,64-66]$. The number of projects considered in this study referred to projects that were initiated under the Malaysian Government's Small Renewable Energy Programme (SREP) in order to promote small-scale renewable electricity in the country. The result showed that solar energy had the most projects in Malaysia in the past, with a total of 38 successful projects. This indicated that solar energy was the most established and reliable technology, which was also supported by Tang et al. [67], who found that this energy system had a high installation capacity compared to the other alternatives. Meanwhile, wind energy was considered to be the least matured technology with a low number of projects in Malaysia. This was due to numerous projects breaking down during operation, which raised concerns about their reliability and longterm prospects [68].

Another sub-criterion under the engineering criteria was the efficiency of the system. Figure 10 shows the efficiency of the renewable energy alternatives. When compared to other resources, mini-hydro energy had the highest output efficiency with an average $67 \%$ efficiency. This was largely due to the availability of water flow throughout the day. The high annual rainfall and river flow also contributed to this, as the abundance of resources benefitted the output efficiency of the energy system [61]. On the other hand, solar energy displayed the lowest efficiency at 11\% compared to other alternatives. This was because of the low purity of the materials used in photovoltaic cells, which resulted in the low overall efficiency of the solar energy system [69]. 


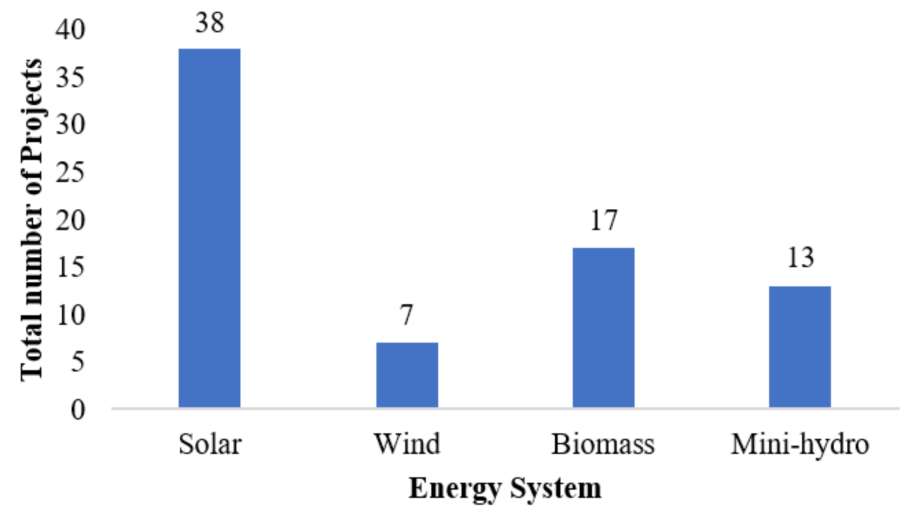

Figure 9. Technology maturity of the renewable energy alternatives [59,64-66].

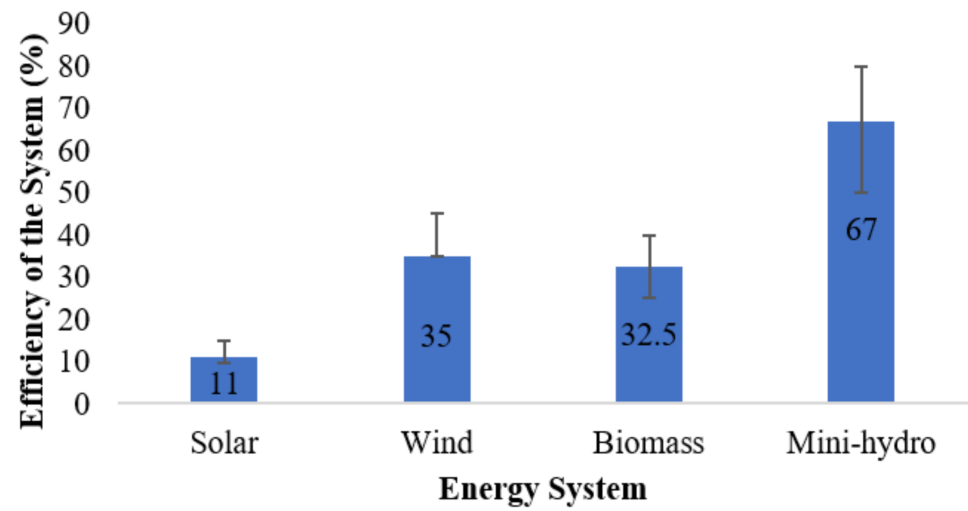

Figure 10. Efficiency of the renewable energy alternatives [70-78].

Following the data collection for the sub-criteria of the AHP model, the importance scores for the criteria and sub-criteria were compiled and normalized. This step was conducted based on the AHP model depicted in Figure 4 from the top level, which was the goal, to the bottom layer of alternatives.

(a) Level 0: Goals To determine the best renewable energy for Tatau, Sarawak.

(b) Level 1: Main Criteria Since the relative weight and score for the criteria were extracted from literature sources with equivalent goals, the pairwise comparison was disregarded at this level. The importance score was derived from a review of the literature. Figure 12 presents the normalized scores that were used to fit the values into the project model.

(c) Level 2: Sub-criteria Figure 11 shows the importance scores for each sub-criterion and the overall importance score for sub-criteria that corresponded to the main criterion, as extracted from the literature sources. All scores were normalized to fit into the AHP model.

(d) Level 3: Alternatives Table 3 tabulates the definition of the importance score and the literature source for each of the environmental, engineering and economic criteria, respectively.

In terms of land requirement, the larger the land area required to build the energy system, the lower the importance score. In this case, solar energy was given the highest priority over the others. The calculation of the score was based on Saaty's importance score of 1-9. The pairwise comparison data were then tabulated and normalized in order to produce the priority vectors shown in Table 4. 
Table 3. Definition of importance score and literature sources for environmental, engineering and economic sub-criteria.

\begin{tabular}{|c|c|c|c|}
\hline Criteria & Sub-Criteria & Definition of Importance Score & Data Source \\
\hline \multirow{5}{*}{ Environmental } & \multirow{4}{*}{ Land requirement } & \multirow{4}{*}{$\begin{array}{c}\text { Larger land required indicates lower } \\
\text { importance score (lower environmental } \\
\text { sustainability) }\end{array}$} & Solar energy: 35 m²/kWh [51] \\
\hline & & & Wind energy: $100 \mathrm{~m}^{2} / \mathrm{kWh}$ [53] \\
\hline & & & Biomass energy: $7000 \mathrm{~m}^{2} / \mathrm{kWh}$ [52] \\
\hline & & & Mini-hydro energy: $961 \mathrm{~m}^{2} / \mathrm{kWh}$ [51] \\
\hline & GWP and AP & $\begin{array}{c}\text { Higher impact value indicates lower } \\
\text { importance score (lower environmental } \\
\text { sustainability) }\end{array}$ & LCA \\
\hline \multirow{11}{*}{ Engineering } & \multirow{3}{*}{ Resource availability } & \multirow{3}{*}{$\begin{array}{l}\text { Higher generation potential indicates } \\
\text { higher importance score (higher } \\
\text { engineering sustainability) }\end{array}$} & $\begin{array}{l}\text { Solar energy: } 6500 \mathrm{MW} \text { [62] } \\
\text { Wind energy: } 1.5 \mathrm{MW}\end{array}$ \\
\hline & & & Biomass energy: 1.7 MW [63] \\
\hline & & & Mini-hydro energy: 28.9 MW [32] \\
\hline & \multirow{4}{*}{ Efficiency of the system } & \multirow{4}{*}{$\begin{array}{c}\text { Higher efficiency indicates higher } \\
\text { importance score (higher engineering } \\
\text { sustainability) }\end{array}$} & Solar energy: $11 \%[62]$ \\
\hline & & & Wind energy: $35 \%$ [71] \\
\hline & & & Biomass energy: $32.5 \%$ [72] \\
\hline & & & Mini-hydro energy: 67\% [70] \\
\hline & \multirow{4}{*}{ Technology maturity } & \multirow{4}{*}{$\begin{array}{l}\text { Higher number of past projects } \\
\text { indicates higher importance score } \\
\text { (higher engineering sustainability) }\end{array}$} & Solar energy: 38 projects [59] \\
\hline & & & Wind energy: 7 projects [65] \\
\hline & & & Biomass energy: 17 projects [66] \\
\hline & & & Mini-hydro energy: 13 projects [64] \\
\hline \multirow[b]{2}{*}{ Economic } & Capital cost & \multirow{2}{*}{$\begin{array}{l}\text { Higher cost indicates lower importance } \\
\text { score (lower economical sustainability). }\end{array}$} & \multirow[b]{2}{*}{ HOMER Pro results } \\
\hline & $\begin{array}{l}\text { Operation and } \\
\text { maintenance cost }\end{array}$ & & \\
\hline
\end{tabular}

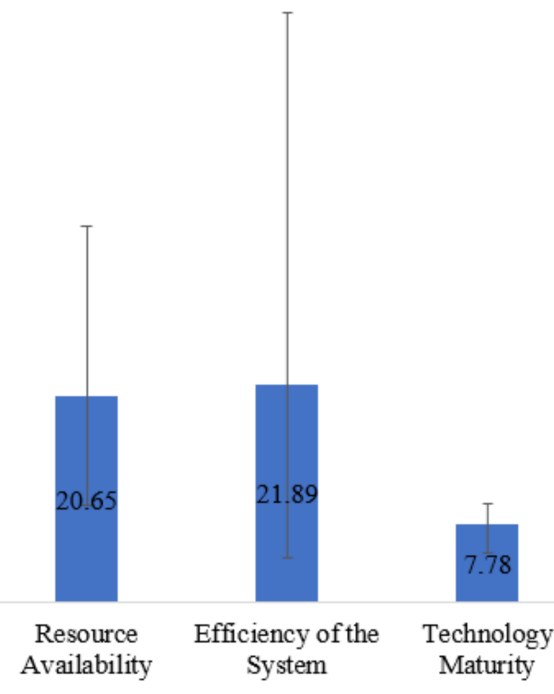
Availability

Sub-Criteria

Figure 11. Overall importance score for sub-criteria [14,15,79-83]. 


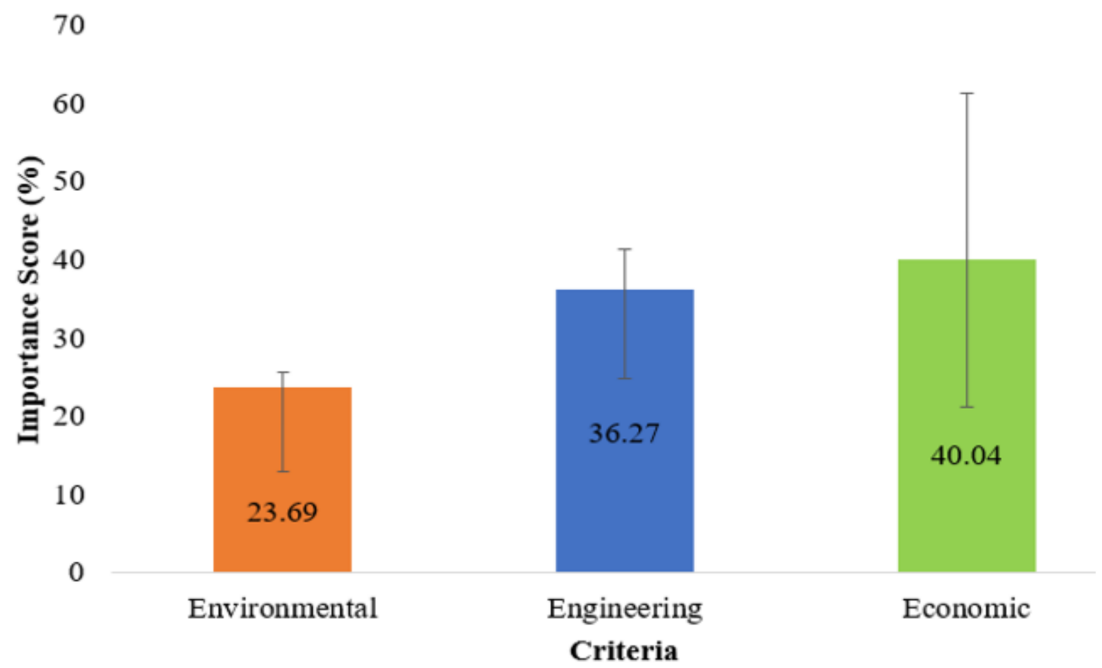

Figure 12. Importance score for main criteria [14,15,79-81].

Table 4. Priority vector with regards to land requirement sub-criterion.

\begin{tabular}{cc}
\hline Energy System & Priority Vector \\
\hline Solar Energy & 0.312 \\
Wind Energy & 0.284 \\
Biomass Energy & 0.180 \\
Mini-hydro Energy & 0.225 \\
\hline
\end{tabular}

The same techniques were used for other sub-criteria in the AHP model. Following that, the linear multiplication of the priority weightings for each segment within all levels for each alternative was conducted in order to determine the final importance score with regards to the AHP model's goal of determining the best renewable energy source in Tatau, Sarawak. Table 5 shows the overall importance scores for all renewable energy alternatives and Table 6 tabulates the final importance scores of all energy sources with respect to the goal of the AHP model.

Table 5. The overall important scores for all renewable energy alternatives.

\begin{tabular}{|c|c|c|c|c|c|c|c|}
\hline \multicolumn{2}{|c|}{ Level 1} & \multicolumn{2}{|c|}{ Level 2} & \multicolumn{4}{|c|}{ Level 3} \\
\hline Criteria & $\begin{array}{l}\text { Importance } \\
\text { Score }\end{array}$ & Sub-Criteria & $\begin{array}{l}\text { Importance } \\
\text { Score }\end{array}$ & $\begin{array}{c}\text { Solar } \\
\text { Energy }\end{array}$ & $\begin{array}{l}\text { Wind } \\
\text { Energy }\end{array}$ & $\begin{array}{l}\text { Biomass } \\
\text { Energy }\end{array}$ & $\begin{array}{l}\text { Mini-hydro } \\
\text { Energy }\end{array}$ \\
\hline \multirow[t]{2}{*}{ Environmental } & \multirow[t]{2}{*}{0.237} & $\begin{array}{l}\text { Land } \\
\text { requirement }\end{array}$ & 0.412 & 0.064 & 0.149 & 0.461 & 0.326 \\
\hline & & LCA & 0.588 & 0.127 & 0.310 & 0.247 & 0.316 \\
\hline \multirow{3}{*}{ Engineering } & \multirow{3}{*}{0.363} & $\begin{array}{c}\text { Resource } \\
\text { availability }\end{array}$ & 0.410 & 0.995 & 0.000 & 0.000 & 0.004 \\
\hline & & $\begin{array}{l}\text { Efficiency of } \\
\text { the system }\end{array}$ & 0.435 & 0.076 & 0.241 & 0.223 & 0.460 \\
\hline & & $\begin{array}{l}\text { Technology } \\
\text { maturity }\end{array}$ & 0.155 & 0.507 & 0.093 & 0.227 & 0.173 \\
\hline \multirow{2}{*}{ Economic } & \multirow{2}{*}{0.400} & Capital cost & 0.562 & 0.207 & 0.199 & 0.324 & 0.270 \\
\hline & & $\mathrm{O} \& \mathrm{M}$ & 0.438 & 0.242 & 0.268 & 0.178 & 0.311 \\
\hline
\end{tabular}


Table 6. The final importance scores of all energy alternatives with respect to the goal of the AHP model.

\begin{tabular}{cc}
\hline Alternatives & Final Importance Score \\
\hline Solar Energy & 0.299 \\
Wind Energy & 0.200 \\
Biomass Energy & 0.230 \\
Mini-hydro Energy & 0.271 \\
\hline
\end{tabular}

The final importance scores for solar, wind, biomass and mini-hydro energy were $0.299,0.200,0.230$ and 0.271 , respectively. In terms of the overall criteria under consideration, which were environmental, engineering, and economic perspectives, solar energy was found to be more sustainable than the other alternatives for the region of Tatau, Sarawak. The main reason for this was the engineering superiority of solar energy over the other alternatives, especially with regards to the resource availability of solar energy in Malaysia. The high solar irradiance of Malaysia outweighed the other resources, as the country is strategically located to have an ideal climate for solar energy [67]. Despite this, other alternatives could still operate within the minimum requirement of the electrical load in the case study area. In terms of technological maturity, the numerous successful solar energy projects in the past have proved that this type of energy system is highly reliable and established in the Malaysia region [68]. This had a significant impact on the decision as other alternatives were either still in development or had failed during previous deployment, thereby casting serious doubt on that energy system, particularly the wind energy system [84].

Despite its excellent engineering characteristics, solar energy underperformed in terms of environmental and economic perspectives, as it received a relatively low importance score in this area. Further research and development can be done in order to discover more affordable and environmentally friendly solar energy systems [84]. This can further mitigate the high energy consumption required for the manufacturing of solar energy components, which is energy intensive and may still rely on fossil fuel sources [85].

\section{Conclusions}

The integrated LCA-AHP approach was successfully applied to determine the best type of renewable energy for the rural area of Tatau, Sarawak. The gate-to-grave LCA was used to assess the manufacturing, construction, usage and end-of-life stages of the renewable energies under evaluation, which were solar, wind, biomass, and mini-hydro energy. Global warming potential (GWP) and acidification potential (AP) were the two environmental impacts that were evaluated. Solar energy had the greatest impact in terms of both GWP and AP, with $104 \mathrm{~kg} \mathrm{CO}_{2}$ eq and $528 \mathrm{~kg} \mathrm{SO}_{2}$ eq, respectively. The least impact among the alternatives was from mini-hydro energy, with a GWP of $10 \mathrm{~kg} \mathrm{CO}_{2}$ eq and an $\mathrm{AP}$ of $42 \mathrm{~kg} \mathrm{SO}_{2}$ eq, indicating that this type of renewable energy was the most sustainable environmental option. In this study, an AHP model was developed in order to determine the best renewable energy source for Tatau, Sarawak based on three criteria, namely environmental, engineering and economic. The hierarchical structure provided an easier route for evaluation, which went through every level, from the goal of the project to the criteria, then to the sub-criteria, and finally to the alternatives. The obtained AHP results differed from the LCA results in that solar energy scored the highest priority weight of 0.299 , compared to $0.200,0.230$ and 0.271 for wind, biomass and minihydro energy, respectively. Although solar energy was not the most sustainable option from an environmental standpoint, the engineering aspect of the energy system was superior compared to the other alternatives, which heavily influenced the decision model. Prior to the actual start of the project, the decision-making process in the energy planning sector is crucial in the determination of the ideal energy system. The LCA-AHP framework in this study was proven to be robust in comparing the renewable energies that were under evaluation. With the input of coordinates for a specific area of interest into the simulation 
software, this framework can also applicable be for other locations, be it in Malaysia or other countries.

Author Contributions: Conceptualization, all authors; Methodology, C.A.J. and J.T.; Software, C.A.J.; Validation, L.S.T., P.L.K. and J.T.; Formal Analysis, C.A.J.; Investigation, C.A.J. and L.S.T.; Resources, L.S.T.; Data Curation, C.A.J. and J.T.; Writing-Original Draft Preparation, C.A.J., J.T. and L.S.T.; Writing-Review \& Editing, J.T., P.L.K., A.M.S. and H.N.A.H.; Visualization, C.A.J. and P.L.K.; Supervision, L.S.T.; Project Administration, L.S.T.; Funding Acquisition, L.S.T., A.M.S. and H.N.A.H. All authors have read and agreed to the published version of the manuscript.

Funding: This research was jointly funded by Universiti Teknologi PETRONAS via the Joint Research Project (JRP8) funding, Universiti Teknologi Malaysia via Matching Grant (PY/2021/00347 \& PY/2021/00272) and Universiti Malaysia Perlis (Grant No: 9023-00022).

Institutional Review Board Statement: Not applicable.

Informed Consent Statement: Not applicable.

Data Availability Statement: The authors confirm that all data generated or analysed to support the findings are included in the published article. The raw data that supports the findings of this study is available upon reasonable request from the corresponding author.

Conflicts of Interest: The authors declare no conflict of interest.

\section{References}

1. Energy Commission, Malaysia Energy Statistics Handbook. 2019. Available online: https://meih.st.gov.my/documents/10620/ bcce78a2-5d54-49ae-b0dc-549dcacf93ae (accessed on 11 November 2020).

2. Abotah, R.; Daim, T.U. Towards building a multi perspective policy development framework for transition into renewable energy. Sustain. Energy Technol. Assess. 2017, 21, 67-88. [CrossRef]

3. Choong, J. Yeo: Malaysia Aiming for 20pc Renewable Energy Use by 2025. Malay Mail. 2019. Available online: https://www. malaymail.com/news/malaysia/2019/09/03/yeo-malaysia-aiming-for-20pc-renewable-energy-use-by-2025/1786768 (accessed on 11 November 2020).

4. Abdullah, W.S.W.; Osman, M.; Ab Kadir, M.Z.A.; Verayiah, R. The potential and status of renewable energy development in Malaysia. Energies 2019, 12, 2437. [CrossRef]

5. Hannan, M.A.; Begum, R.A.; Abdolrasol, M.G.; Lipu, M.H.; Mohamed, A.; Rashid, M.M. Review of baseline studies on energy policies and indicators in Malaysia for future sustainable energy development. Renew. Sustain. Energy Rev. 2018, 94, 551-564. [CrossRef]

6. Sreeraj, E.S.; Chatterjee, K.; Bandyopadhyay, S. Design of isolated renewable hybrid power systems. Sol. Energy 2010, 84, 1124-1136. [CrossRef]

7. Chen, S. Rural electrification in Sarawak, Malaysia: Potential \& Challenges for Mini-Hydro \& Solar Hybrid Solutions. 2016. Available online: https://www.eclareon.com/sites/default/files/Presentations/04_chen_shiun.pdf (accessed on 10 January 2021).

8. Khengwee, T.; Hoole, P.R.P.; Pirapaharan, K.; Julai, N.; Othman, A.K.H.; Anyi, M.; Haidar, A.M.A.; Hoole, S.R.H. A review of Sarawak off-grid renewable energy potential and challenges. J. Telecommun. Electron. Comput. Eng. 2017, 9, $29-33$.

9. Foster, R.; Ghassemi., M.; Cota, A. Solar Energy: Renewable Energy and the Environment; CRC Press: Florida, FL, USA, 2009.

10. Campos-Guzmán, V.; García-Cáscales, M.S.; Espinosa, N.; Urbina, A. Life cycle analysis with multi-criteria decision making: A review of approaches for the sustainability evaluation of renewable energy technologies. Renew. Sustain. Energy Rev. 2019, 104, 343-366. [CrossRef]

11. De Marco, I.; Riemma, S.; Iannone, R. Life cycle assessment of supercritical $\mathrm{CO}_{2}$ extraction of caffeine from coffee beans. J. Supercrit. Fluid. 2018, 133, 393-400. [CrossRef]

12. Gallucci, T.; Lagioia, G.; Piccinno, P.; Lacalamita, A.; Pontrandolfo, A.; Paiano, A. Environmental performance scenarios in the production of hollow glass containers for food packaging: An LCA approach. Int. J. Life Cycle Assess. 2021, 26, 785-798. [CrossRef]

13. Bhole, G.P.; Deshmukh, T. Multi criteria decision making (MCDM) methods and its applications. Int. J. Appl. Sci. Eng. 2018, 6, 899-915. [CrossRef]

14. Al Garni, H.; Kassem, A.; Awasthi, A.; Komljenovic, D.; Al-Haddad, K. A multicriteria decision making approach for evaluating renewable power generation sources in Saudi Arabia. Sustain. Energy Technol. Assess. 2016, 16, 137-150. [CrossRef]

15. Algarín, C.R.; Llanos, A.P.; Castro, A.O. An analytic hierarchy process based approach for evaluating renewable energy sources. Int. J. Energy Econ. Policy 2017, 7, 38-47.

16. Das, A.; Shabbiruddin. Renewable energy source selection using analytical hierarchy process and quality function deployment: A case study. In Proceedings of the 2016 Second International Conference on Science Technology Engineering and Management (ICONSTEM), Chennai, India, 30-31 March 2016; IEEE: New York, NY, USA, 2016; pp. 298-302. 
17. Hilorme, T.; Tkach, K.; Dorenskyi, O.; Katerna, O.; Durmanov, A. Decision making model of introducing energy-saving technologies based on the analytic hierarchy process. J. Manag. Inf. Decis. Sci. 2019, 22, 489-494.

18. Zhang, L.Y.; Li, C.X.; Phuong, N.H. Development of biomass energy industry in Heilongjiang Province based on analytic hierarchy process. Nat. Environ. Pollut. Technol. 2019, 18, 1487-1493.

19. Ren, J.Z.; Manzardo, A.; Mazzi, A.; Zuliani, F.; Scipioni, A. Prioritization of bioethanol production pathways in China based on life cycle sustainability assessment and multicriteria decision-making. Int. J. Life Cycle Assess. 2015, 20, 842-853. [CrossRef]

20. Basri, N.A.; Ramli, A.T.; Aliyu, A.S. Malaysia energy strategy towards sustainability: A panoramic overview of the benefits and challenges. Renew. Sustain. Energy Rev. 2015, 42, 1094-1105. [CrossRef]

21. Kim, T.H.; Chae, C.U. Environmental impact analysis of acidification and eutrophication due to emissions from the production of concrete. Sustainability 2016, 8, 578. [CrossRef]

22. Ludin, N.A.; Mustafa, N.I.; Hanafiah, M.M.; Ibrahim, M.A.; Teridi, M.A.M.; Sepeai, S.; Sopian, K. Prospects of life cycle assessment of renewable energy from solar photovoltaic technologies: A review. Renew. Sustain. Energy Rev. 2018, 96, 11-28. [CrossRef]

23. Bahta, S.T. Design and Analyzing of an Off-Grid Hybrid Renewable Energy System to Supply Electricity for Rural Areas: Case Study: Atsbi District, North Ethiopia. Master's Thesis, KTH School of Industrial Engineering and Management, Stockholm, Sweden, 2016.

24. Ishikawa, N.; Soda, R. Anthropogenic Tropical Forests: Human-Nature Interfaces on the Plantation Frontier; Springer Nature: Singapore, 2019.

25. Jong, F.C.; Ahmed, M.M.; Aik, D.L.H. Integration of renewable energy sources optimization in Sarawak using GIS and MCDMAHP. In Proceedings of the 2019 International UNIMAS STEM 12th Engineering Conference (EnCon), Sarawak, Malaysia, 28-29 August 2019; pp. 65-70.

26. Trowell, K.A.; Goroshin, S.; Frost, D.L.; Bergthorson, J.M. Aluminum and its role as a recyclable, sustainable carrier of renewable energy. Appl. Energy 2020, 275, 115112. [CrossRef]

27. Natural Gas Conversion Guide 2012, International Gas Union. Available online: http://agnatural.pt/documentos/ver/naturalgas-conversion-guide_cb4f0ccd80ccaf88ca5ec336a38600867db5aaf1.pdf (accessed on 21 April 2020).

28. Gómez, M.R.; Garcia, R.F.; Gómez, J.R.; Carril, J.C. Review of thermal cycles exploiting the exergy of liquefied natural gas in the regasification process. Renew. Sustain. Energy Rev. 2014, 38, 781-795. [CrossRef]

29. Huang, Y.F.; Gan, X.J.; Chiueh, P.T. Life cycle assessment and net energy analysis of offshore wind power systems. Renew. Energy 2017, 102, 98-106. [CrossRef]

30. Kaab, A.; Sharifi, M.; Mobli, H.; Nabavi-Pelesaraei, A.; Chau, K.W. Combined life cycle assessment and artificial intelligence for prediction of output energy and environmental impacts of sugarcane production. Sci. Total Environ. 2019, 664, 1005-1019. [CrossRef] [PubMed]

31. Yuguda, T.K.; Li, Y.; Xiong, W.; Zhang, W. Life cycle assessment of options for retrofitting an existing dam to generate hydroelectricity. Int. J. Life Cycle Assess. 2020, 25, 57-72. [CrossRef]

32. Hussein, I.; Raman, N. Reconnaissance studies of micro hydro potential in Malaysia. In Proceedings of the International Conference on Energy and Sustainable Development: Issues and Strategies, Chiang Mai, Thailand, 2-4 June 2010; pp. 1-10.

33. Promentilla, M.A.B.; Aviso, K.B.; Lucas, R.I.G.; Razon, L.F.; Tan, R.R. Teaching Analytic Hierarchy Process (AHP) in undergraduate chemical engineering courses. Educ. Chem. Eng. 2018, 23, 34-41. [CrossRef]

34. Saaty, T.L. The Analytic Hierarchy Process: Planning, Priority Setting, Resource Allocation. McGraw Hill International: New York, NY, USA, 1980.

35. Frischknecht, R.; Jungbluth, N.; Althaus, H.J.; Doka, G.; Dones, R.; Heck, T.; Hellweg, S.; Hischier, R.; Nemecek, T.; Rebitzer, G.; et al. The ecoinvent database: Overview and methodological framework. Int. J. Life Cycle Assess. 2005, 10, 3-9. [CrossRef]

36. Ahmad Ludin, N.; Ahmad Affandi, N.A.; Purvis-Roberts, K.; Ahmad, A.; Ibrahim, M.A.; Sopian, K.; Jusoh, S. Environmental impact and levelised cost of energy analysis of solar photovoltaic systems in selected Asia Pacific region: A cradle-to-grave approach. Sustainability 2021, 13, 396. [CrossRef]

37. Ghenai, C. Life cycle analysis of wind turbine. In Sustainable Development-Energy, Engineering and Technologies-Manufacturing and Environment; Ghenai, C., Ed.; InTech: Rijeka, Croatia, 2012; pp. 19-32.

38. Emissions, G.G. Comparison of Lifecycle Greenhouse Gas Emissions of Various Electricity Generation Sources. 2011. Available online: https:/ /gssd.mit.edu/search-gssd/site/comparison-lifecycle-greenhouse-gas-61507-tue-10-31-2017-2350 (accessed on 10 January 2021).

39. Bergerson, J.; Lave, L. A Life Cycle Analysis of Electricity Generation Technologies. Health and Environmental Implications of Alternative Fuels and Technologies. 2002. Available online: https://www.cmu.edu/ceic/assets/docs/publications/workingpapers / ceic-03-05.pdf (accessed on 21 April 2020).

40. Shen, X.; Kommalapati, R.R.; Huque, Z. The comparative life cycle assessment of power generation from lignocellulosic biomass. Sustainability 2015, 7, 12974-12987. [CrossRef]

41. Pang, M.; Zhang, L.; Wang, C.; Liu, G. Environmental life cycle assessment of a small hydropower plant in China. Int. J. Life Cycle Assess. 2015, 20, 796-806. [CrossRef]

42. Hanafi, J.; Riman, A. Life cycle assessment of a mini hydro power plant in Indonesia: A case study in Karai River. Procedia Cirp. 2015, 29, 444-449. [CrossRef]

43. Mulvaney, D. Solar's green dilemma. IEEE Spectr. 2014, 51, 30-33. [CrossRef] 
44. Gomaa, M.R.; Rezk, H.; Mustafa, R.J.; Al-Dhaifallah, M. Evaluating the environmental impacts and energy performance of a wind farm system utilizing the life-cycle assessment method: A practical case study. Energies 2019, 12, 3263. [CrossRef]

45. Chipindula, J.; Botlaguduru, V.S.V.; Du, H.; Kommalapati, R.R.; Huque, Z. Life cycle environmental impact of onshore and offshore wind farms in Texas. Sustainability 2018, 10, 2022. [CrossRef]

46. Raadal, H.L.; Gagnon, L.; Modahl, I.S.; Hanssen, O.J. Life cycle greenhouse gas (GHG) emissions from the generation of wind and hydro power. Renew. Sustain. Energy Rev. 2011, 15, 3417-3422. [CrossRef]

47. Carrasco, L.M.; Narvarte, L.; Lorenzo, E. Operational costs of A 13,000 solar home systems rural electrification programme. Renew. Sustain. Energy Rev. 2013, 20, 1-7. [CrossRef]

48. Albani, A.; Ibrahim, M.Z. Wind energy potential and power law indexes assessment for selected near-coastal sites in Malaysia. Energies 2017, 10, 307. [CrossRef]

49. Naqvi, M.; Yan, J.; Dahlquist, E.; Naqvi, S.R. Off-grid electricity generation using mixed biomass compost: A scenario-based study with sensitivity analysis. Appl. Energy 2017, 201, 363-370. [CrossRef]

50. Dorber, M.; May, R.; Verones, F. Modeling net land occupation of hydropower reservoirs in Norway for use in life cycle assessment. Environ. Sci. Technol. 2018, 52, 2375-2384. [CrossRef] [PubMed]

51. Fthenakis, V.; Kim, H.C. Land use and electricity generation: A life-cycle analysis. Renew. Sustain. Energy Rev. 2009, 13, 1465-1474. [CrossRef]

52. Oliver, A.; Khanna, M. Demand for biomass to meet renewable energy targets in the United States: Implications for land use. GCB Bioenergy 2017, 9, 1476-1488. [CrossRef]

53. van Zalk, J.; Behrens, P. The spatial extent of renewable and non-renewable power generation: A review and meta-analysis of power densities and their application in the US. Energy Policy 2018, 123, 83-91. [CrossRef]

54. Jha, S.K.; Puppala, H. Prospects of renewable energy sources in India: Prioritization of alternative sources in terms of Energy Index. Energy 2017, 127, 116-127. [CrossRef]

55. Nonhebel, S. Renewable energy and food supply: Will there be enough land? Renew. Sustain. Energy Rev. 2005, 9, 191-201. [CrossRef]

56. Lam, H.L.; Varbanov, P.S.; Klemeš, J.J. Regional renewable energy and resource planning. Appl. Energy 2011, 88, 545-550. [CrossRef]

57. Alola, A.A.; Alola, U.V. Agricultural land usage and tourism impact on renewable energy consumption among Coastline Mediterranean Countries. Energy Environ. 2018, 29, 1438-1454. [CrossRef]

58. Fauzi, M.A.; Setyono, P.; Pranolo, S.H. Environmental assessment of a small power plant based on palm kernel shell gasification. In Proceedings of the International Conference on Science and Applied Science; AIP Publishing LLC: Surakarta, Indonesia, 2020; Volume 2296, p. 020038.

59. Vaka, M.; Walvekar, R.; Rasheed, A.K.; Khalid, M. A review on Malaysia's solar energy pathway towards carbon-neutral Malaysia beyond Covid'19 pandemic. J. Clean. Prod. 2020, 273, 122834. [CrossRef] [PubMed]

60. Petinrin, J.O.; Shaaban, M. Renewable energy for continuous energy sustainability in Malaysia. Renew. Sustain. Energy Rev. 2015, 50, 967-981. [CrossRef]

61. Sa'adi, Z.; Shahid, S.; Ismail, T.; Chung, E.S.; Wang, X.J. Distributional changes in rainfall and river flow in Sarawak, Malaysia. Asia Pac. J. Atmos. Sci. 2017, 53, 489-500. [CrossRef]

62. Solangi, K.H.; Islam, M.R.; Saidur, R.; Rahim, N.A.; Fayaz, H. A review on global solar energy policy. Renew. Sustain. Energy Rev. 2011, 15, 2149-2163. [CrossRef]

63. Chang, Y.; Phoumin, H. Harnessing wind energy potential in ASEAN: Modelling and policy implications. Sustainability 2021, 13, 4279. [CrossRef]

64. Hossain, M.; Huda, A.S.N.; Mekhilef, S.; Seyedmahmoudian, M.; Horan, B.; Stojcevski, A.; Ahmed, M. A state-of-the-art review of hydropower in Malaysia as renewable energy: Current status and future prospects. Energy Strategy Rev. 2018, 22, 426-437. [CrossRef]

65. Bong, C.P.C.; Ho, W.S.; Hashim, H.; Lim, J.S.; Ho, C.S.; Tan, W.S.P.; Lee, C.T. Review on the renewable energy and solid waste management policies towards biogas development in Malaysia. Renew. Sustain. Energy Rev. 2017, 70, 988-998. [CrossRef]

66. Umar, M.S.; Urmee, T.; Jennings, P. A policy framework and industry roadmap model for sustainable oil palm biomass electricity generation in Malaysia. Renew. Energy 2018, 128, 275-284. [CrossRef]

67. Tang, S.; Chen, J.; Sun, P.; Li, Y.; Yu, P.; Chen, E. Current and future hydropower development in Southeast Asia countries (Malaysia, Indonesia, Thailand and Myanmar). Energy Policy 2019, 129, 239-249. [CrossRef]

68. Noman, F.; Alkawsi, G.; Abbas, D.; Alkahtani, A.; Tiong, S.K.; Ekanyake, J. A Comprehensive Review of Wind Energy in Malaysia: Past, Present and Future Research Trends. IEEE Access 2020, 8, 124526-124543. [CrossRef]

69. Sampaio, P.G.V.; González, M.O.A. Photovoltaic solar energy: Conceptual framework. Renew. Sustain. Energy Rev. 2017, 74, 590-601. [CrossRef]

70. Quaranta, E.; Revelli, R. Output power and power losses estimation for an overshot water wheel. Renew. Energy 2015, 83, 979-987. [CrossRef]

71. Rawat, R.; Lamba, R.; Kaushik, S.C. Thermodynamic study of solar photovoltaic energy conversion: An overview. Renew. Sustain. Energy Rev. 2017, 71, 630-638. [CrossRef] 
72. Lee, J.Y.; An, S.; Cha, K.; Hur, T. Life cycle environmental and economic analyses of a hydrogen station with wind energy. Int. J. Hydrog. Energy 2010, 35, 2213-2225. [CrossRef]

73. Nzihou, A. Handbook on Characterization of Biomass, Biowaste and Related by-Products; Springer Nature: Cham, Switzerland, 2020.

74. Goswami, D.Y.; Kreith, F. Handbook of Energy Efficiency and Renewable Energy; CRC Press: Boca Raton, FL, USA, 2007.

75. Akram, R.; Chen, F.; Khalid, F.; Ye, Z.; Majeed, M.T. Heterogeneous effects of energy efficiency and renewable energy on carbon emissions: Evidence from developing countries. J. Clean. Prod. 2020, 247, 119122. [CrossRef]

76. Leal Filho, W.; Salvia, A.L.; Do Paco, A.; Anholon, R.; Quelhas, O.L.G.; Rampasso, I.S.; Brandli, L.L. A comparative study of approaches towards energy efficiency and renewable energy use at higher education institutions. J. Clean. Prod. 2019, 237, 117728. [CrossRef]

77. Garrett-Peltier, H. Green versus brown: Comparing the employment impacts of energy efficiency, renewable energy, and fossil fuels using an input-output model. Econ. Model. 2017, 61, 439-447. [CrossRef]

78. Stavropoulos, S.; Burger, M.J. Modelling strategy and net employment effects of renewable energy and energy efficiency: A meta-regression. Energy Policy 2020, 136, 111047. [CrossRef]

79. Amer, M.; Daim, T.U. Selection of renewable energy technologies for a developing county: A case of Pakistan. Energy Sustain. Dev. 2011, 15, 420-435. [CrossRef]

80. Ahmad, S.; Tahar, R.M. Selection of renewable energy sources for sustainable development of electricity generation system using analytic hierarchy process: A case of Malaysia. Renew. Energy 2014, 63, 458-466. [CrossRef]

81. Wang, Y.; Xu, L.; Solangi, Y.A. Strategic renewable energy resources selection for Pakistan: Based on SWOT-Fuzzy AHP approach. Sustain. Cities Soc. 2020, 52, 101861. [CrossRef]

82. Abushammala, M.F.; Qazi, W.A. Evaluation of the significant renewable energy resources in Sultanate of Oman using Analytical Hierarchy Process. Int. J. Renew. Energy Res. 2018, 8, 1528-1534.

83. Ishfaq, S.; Ali, S.; Ali, Y. Selection of optimum renewable energy source for energy sector in Pakistan by using MCDM approach. Process Integr. Optim. Sustain. 2018, 2, 61-71. [CrossRef]

84. Whitacre, P. Sustainable Materials and Manufacturing for Renewable Energy Technology Development to 2030: Proceedings of a Workshopin Brief; The National Academies Press: Washington, DC, USA, 2017.

85. Martinopoulos, G. Life cycle assessment of solar energy conversion systems in energetic retrofitted buildings. J. Build. Eng. 2018, 20, 256-263. [CrossRef] 